Article

\title{
Post-Brexit Leadership in European Finance
}

\author{
Sven Van Kerckhoven ${ }^{1,2}$ \\ ${ }^{1}$ Vesalius College, Vrije Universiteit Brussel, 1050 Brussels, Belgium; E-Mail: sven.van.kerckhoven@vub.be \\ 2 Institute for European Studies, Vrije Universiteit Brussel, 1050 Brussels, Belgium
}

Submitted: 30 September 2020 | Accepted: 21 December 2020 | Published: 27 January 2021

\begin{abstract}
Brexit has far-reaching consequences for Europe and the European single market for financial transactions. In particular in this field, the UK has had a strong influence in drafting European policies and legislation as the City of London has acted as the financial hub in Europe for several decades. As a result, the UK has spearheaded the call for more market friendly legislation with the support of some other EU member states. This went against the wishes of several other EU member states, where a stronger rule-based approach to financial markets was strongly preferred, in particular after the financial crisis clearly demonstrated weaknesses in the macroeconomic oversight of European financial markets. With the UK leaving, the call for more stringent legislation will gain momentum as the political leadership among the remaining $27 \mathrm{EU}$ member states will shift and might be looking to curtail the long-standing dominant position of the UK in the field of financial industries. In this light, several leaders of EU27 member states have already voiced their support for their nations' financial hub to become the next City of London. This would lead to a substantial change in leadership in European finance post-Brexit. This contribution assesses the impact of Brexit on the changes in political leadership on the governance of European financial markets, as they might ultimately be reflected in the institutional outcomes and policies.
\end{abstract}

\section{Keywords}

Brexit; European Union; finance; Frankfurt; Paris; political culture; political leadership

\section{Issue}

This article is part of the issue "What Brexit Means for Europe: EU Institutions and Actors after the British Referendum" edited by Edoardo Bressanelli (Sant'Anna School of Advanced Studies, Italy) and Nicola Chelotti (Loughborough University London, UK).

(C) 2021 by the author; licensee Cogitatio (Lisbon, Portugal). This article is licensed under a Creative Commons Attribution 4.0 International License (CC BY).

\section{Introduction}

On 23 June 2016, the citizens of the UK decided through a referendum vote to leave the EU. The UK government formally informed the EU of its decision to leave the Union on 29 March 2017. After the two years withdrawal period, the UK was thus expected to leave the EU by 29 March 2019. As no agreement could be found by that date, the UK requested, and was granted, an extension until 31 January 2020 after which the UK officially left the UK, with a transition period lasting until the end of 2020.

After joining the European Communities in 1973, the UK and the EU have moved together for almost 50 years, which helps to explain the many issues and the long time frame of the withdrawal process. As one of the largest members of the EU, the UK always had a strong impact on European decision-making. In certain areas, its role has been even bigger due to the nature of the UK's industry and interests.

One such area is the financial sector. Globally, the UK is the largest exporter of financial services, and approximately one third of that exports goes to the EU. Over the years, the UK, and in particular the City of London, has grown into the main hub for financial services in Europe. Through its well-developed infrastructure and its historical growth, the City of London has ensured that it clears and manages the majority of Euro-denominated financial transactions.

The City of London is not just the European financial hub; but also serves as the nexus between international finance and the EU. The City's role as a broker between international and European companies has 
grown historically. By the start of the 20th century, many American stock exchanges frequently used clearing houses. At that time, London was the only European stock exchange working with a clearing house, giving it a significant first mover advantage. The result is that over time the City of London came to substantially outsize other European financial hubs in terms of foreignregistered monetary financial institutions, making it the main international finance hub in the EU. It is also the place where most EU area and third country institutions (mostly headquarter in the US and Switzerland) have set up a large presence, as foreign financial firms currently benefit from the fact that the UK license gives them access to a European passport (see Schoenmaker, 2017). European financial integration thus greatly benefited the open and competitive UK financial sector.

Since Brexit, discussions on the location of financial services and the future of financial supervision have heated up and attracted significant attention from policymakers and media outlets. At the current time, it is yet unclear what the exact impact of Brexit would be on the location and oversight of the financial industry. Never before has one of the world's largest economic areas been decoupled from its financial capital. Few and less outspoken historical examples include Vienna, that after WWI ceased to be the financial capital of the defeated and dismantled Austro-Hungarian empire, and Montreal, which was replaced as Canada's financial capital by Toronto as a result of Quebec's separatism.

Part IV of the political declaration setting out the framework for the future relationship between the EU and the UK refers to financial services, but gives little indication on what the future relationship may look like in this field. It states that "the Parties are committed to preserving financial stability, market integrity, investor and consumer protection and fair competition, while respecting the Parties' regulatory and decision-making autonomy, and their ability to take equivalence decisions in their own interest" (European Commission, 2019b, p. 5). It notes the parties have equivalence frameworks in place to recognise each other's regulatory and supervisory regimes and agree to close a structured cooperation on regulatory and supervisory matters. Beyond this, the withdrawal agreement and political declaration give little guidance on what the UK's relationship will be in these fields post-Brexit.

However, it is clear that as the UK will be leaving the $\mathrm{EU}$, it will no longer be able to have a direct influence on the direction in which the governance of European financial market develops. This has serious repercussions for the political leadership in European finance, currently heavily influenced by the UK. The next section provides a review of the literature on Brexit on European finance. After establishing that a focus on post-Brexit leadership with regards to the governance of the EU single market of financial services has been lacking, Section 3 then discusses the application of political leadership in EU studies. Section 4 then describes how political leadership in
European finance will shift from the UK to France or Germany, and how this change will impact the governance of the EU financial markets. Section 5 concludes.

\section{The Impact of Brexit on European Finance}

The impact of Brexit on the UK has attracted a significant amount of attention, from scholars and news outlets. Most of the scholarly contributions have focused on either explaining the referendum outcome (e.g., Curtice, 2017; Goodwin \& Heath, 2016), or on assessing the impact of the withdrawal on the UK (e.g., Begg \& Mushövel, 2016; Bloom et al., 2019). More recently, attention has also been devoted to the impact of Brexit on EU policies (e.g., the thematic issue on the impact of Brexit on EU policies; De Ville \& Siles-Brügge, 2019).

The literature focusing on the impact of Brexit on financial governance and the financial industry is a bit more limited, and has focused broadly on 1) the economic impact of Brexit, 2) the governance of the EU financial single market, and 3) the role of the City of London as international financial center. An initial investigation of the economic impact of Brexit on the UK's financial market has made clear that the UK is at risk of losing significant income and jobs as a result of their withdrawal (Batsaikhan, Kalcik, \& Schoenmaker, 2017). The financial industry represents some $7 \%$ of GDP and generates major exports for the UK. The export of financial services is estimated to be affected most strongly among all exports of services (Rehman \& Della Posta, 2018). In light of its importance, the financial industry in London has historically received significant protection from the UK government, but as freedom of movement issues have dominated commercial interests in the buildup and aftermath of the referendum (Thompson, 2017). The impact on the EU27 is expected to be much smaller, and might be even positive (Van Kerckhoven \& Odermatt, 2020), but could result in additional costs for companies both in the UK as well as in the EU (UK Government's Actuary Department, 2017). However, it is clear that the overall impact strongly depends on the eventual outcome of the ongoing negotiations (Armour, 2017).

Brexit would also impact the governance of the European financial markets. The exact impact is currently difficult to assess as the withdrawal negotiations are still taking place. National central banks within the EU have different legal rules, risking competition on regulatory and supervisory practices between member states (European Securities and Markets Authority, 2017). After Brexit, the greatest uncertainty relates to the EU's evolving supervisory/institutional arrangements which will be drafted without UK involvement (Moloney, 2018), whereby the European Supervisory Agencies could play a larger role (Moloney, 2016). In light of this uncertainty, one could expect the financial industry to collaborate intensively across member states. However, Howarth and Quaglia (2018) have argued that, rather than witnessing cross-national alliances of financial industry 
members advocating broad access for the UK to the EU single market in financial services, the main financial centers in the EU27 and their national authorities have been competing to lure financial business away from the UK. However, such a competition between member states favoring a relocation of the UK-based financial services to the EU27 poses certain challenges with regards to the governance of European financial markets (Lavery, McDaniel, \& Schmid, 2019).

A relocation would greatly impact the role of the City of London as one of the major international financial centers. From the 19th century onwards, London became one of the global centres for lending and investment. Due to the leading role taken up by London as well as the US in dealing with, as well as in developing, financial products, English contract law became widely adopted for international finance, whereby the legal services where often provided in London (Wood, 2008). London was always an international rather than a domestic financial centre, far more than New York, Frankfurt, Paris or Tokyo. In a similar vein, the City of London grew to become the European financial centre, in particular in wholesale financial services, slowly overtaking other European financial centres, such as Frankfurt, Paris and Amsterdam. This has spurred the development of a whole industry dealing with financials services in the UK.

Another factor that has spurred the development of London as the premier European financial centre relates to clearing houses. By the start of the 20th century, many US stock exchanges frequently used clearing houses. At that time, London was the only European stock exchange working with a clearing house, giving it a significant first mover advantage. The role of clearing houses was further expanded in the wake of the 2008 financial crisis. At the 2009 G20 meeting in Pittsburgh, the leaders of the $\mathrm{G} 20$ decided that all standardized derivatives contracts should be traded on exchanges and cleared by clearinghouses (Wouters, Van Kerckhoven, \& Odermatt, 2013). Because of this $G 20$ decision, London was able to further strengthen its position as the prime international financial hub in the EU due to its leading role in interest rate over the-counter derivatives (75\% of all transactions denominated in euro; Batsaikhan et al., 2017). Moreover, the $G 20$ decision resulted in the need to novate a wide variety of over-the-counter derivatives, ensuring that clearing is essentially and increasingly so, the backbone of modern financial markets. Post-Brexit, it is anticipated that the UK would lose some of its power in the clearing houses business (Van Kerckhoven \& Odermatt, 2020).

An issue that so far has failed to attract scholarly attention is that Brexit also leads to a shift in leadership in the European single financial market. With the UK potentially at the sideline of EU financial decisionmaking, some other member states will receive a larger leading role in the governance of the EU single market in financial services. Leadership post-Brexit has been investigated in light of other issue fields (Tömmel \& Verdun,
2017), such as climate change (Dupont \& Moore, 2019) and in relation to the role of certain countries (Krotz \& Schild, 2018), but an in-depth investigation in what the impact of Brexit entails for leadership in European finance has been lacking. This is all the more surprising since compared to other issue fields, the impact of Brexit on leadership is arguably more substantial in the field of European finance.

\section{Ideational and Coercive Political Leadership and the EU}

Brexit will impose a tremendous shift in the European political landscape dealing with finance and the financial industry. This article aims to add to this literature by focusing on how Brexit changes the political leadership within the EU's financial governance. Leadership can be approached as an input dimension in the political decision-making, that through the decision-making process, influences the outcomes, as witnessed in policies and decision-making. As currently, Brexit has not lead to a change in the EU decision-making processes, and assessing outcomes is premature, focusing on the changing leadership as an input dimension into the political process allows us to shed a light on how the EU's approach towards finance might change, and will influence institutional outcomes in the future.

Political leadership has been the subject of studies, both theoretical and empirical, for several decades (starting with the seminal work of Burns, 1978). However, within this growing body of scholarly work, consensus on a definition is still missing. Moreover, a variety of approaches have been employed to the study of political leadership. Consequently, there is a wide variety and a deep richness in its study, but the concept itself remains ill-defined (Elgie, 2001). During the last decade, increasing scholarly attention has been devoted to 'political leadership in the EU.' This literature focuses often on individuals or individual institutions, for example, Cini (2008) and Tömmel $(2013,2020)$ have investigated the European Commission presidents from a leadership perspective. In a similar vein, the presidents of the Council and the European Council have been studied extensively (Bunse, 2009; Dinan, 2013; Tallberg, 2006) as well as the EU High Representatives (Koops \& Tercovich, 2020). In a similar vein, research has studied the leadership of institutions, such as the European Central Bank (Verdun, 2017) or the European Parliament (Shackleton, 2017).

The particular set-up of the Union means that leadership should be perceived differently than in nation states. The fragmented character of European polity, and the dense web of institutions and network structures, warrant a specific focus. In this light, the role of member states is not to be underestimated. Indeed, individual member states steer the agenda and decision-making of the EU.

An in-depth overview of how Brexit can lead to a shift in European leadership in the financial sector and 
its oversight is so far missing. This article adds to the literature by looking into the two dimensions of leadership: Ideational leadership and coercive leadership and studies how they impact the governance of EU single market for financial services after Brexit. In essence, this lens allows to answer the questions: 1 ) Who would lead political decisions related to financial governance?; and 2) what would be the impact of the changing leadership on the content of financial policies?

Coercive leadership provides an angle to answer the first of these questions. It relates to the instances in which one party gathers leverage over the other party. This could for example be the fact that one member state has access to resources that are useful to the other party who might lack access to these resources. In this case, interest-based hard bargaining can take place between member states (Milward, 1992), whereby the outcome is often influenced by the resources and pressure exercised by the different member states (Keohane $\&$ Nye, 1989). In such a setting, the bargaining among resourceful member states interacts with endogenous factors such as potential coalitions available. Public statements and media are often used in order to support the bargaining strategies. In all issue fields, as in finance, coercive leadership requires clout in the specific issue field. In terms of size and overall influence, it has often argued that proposals without the support of powerful member states such as France, Germany and the UK stand little chance in passing, whereas proposals that are supported by them are in general accepted (Bulmer \& Paterson, 2013; Schild, 2010). Agreement between the powerful member states often leads to swift action, whereas disagreement often results in delayed decisionmaking. Of course, with the UK leaving the EU, several of the findings of previous literature might no longer hold. An initial investigation proposes that after Brexit three scenarios are likely in terms of the countries taking the lead in the EU, of which the most probable is a strong Franco-German relationship (Krotz \& Schild, 2018). The UK, as the other major powerhouse, has often been perceived as an awkward partner to the European integration project (George, 1998). Notwithstanding this general statement, it is clear that this does not hold for all issue fields (Daddow \& Oliver, 2016). However, as argued below, the UK has often found itself at disagreement with several other EU member states when it comes to regulating financial markets. Complementarily, member states yield more weight in issue fields where they have larger resources. In European finance, having a strong financial industry would provide a member state with a larger influence at the negotiation table.

To answer the question on what the impact on the policies of the changed leadership could be, we turn to ideational leadership. Ideational leadership can be defined as the capacity of actors to influence other actors' normative and cognitive beliefs through the use of ideational elements (Carstensen \& Schmidt, 2018). Exercising leadership then happens through persuasion or occurs through the imposition of ideas. Policy proposals are then framed in relations to underlying ideas, that could be deeply rooted in societies. Within European decision-making, individual member states' heads of state or government play an important role, both directly in the European Council, as indirectly as representatives of their national constituency. These leaders are elected in their national environment, and often act in order to represent their national interests, which have often been shaped historically. These leaders' actions are thus influenced by their national culture which is impacted by current and historical predispositions on how companies should be regulated and deep-rooted beliefs on the structure of economies.

The extent to which individual member states apply ideational and coercive leadership depends on the specific importance of the issue for their national economies. When Heads of government or state care strongly about a specific issue field, they will exercise more leadership in order to attain an outcome that is close to their national interests.

Several scholars have tended to focus on the 'static effects' of Brexit, by looking at what the EU and its policies would look like if the UK was simply taken out of the "EU 'equation"' (Jacobs, 2018; Jensen \& Snaith, 2018, p. 255). The focus on leadership in European finance taken in this article allows for a 'dynamic' investigation. As Brexit involves actors that continuously adjust their preferences and/or strategies, such an approach shows greater promise (De Ville \& Siles-Brügge, 2019), and gives the ability to assess potential future developments. In order to assess the impact of Brexit on the governance of EU finance, this article builds upon scholarly work, and related publications, such as report and public statements.

\section{Shifting Leadership in European Finance}

The decision of the UK to leave the EU has triggered a wide variety of questions related to the future of the City of London as financial hub, and the future evolution of the EU single market in financial services. The extent to which the remaining EU members and the UK will continue to cooperate crucially depends on the outcome of the ongoing negotiations and the final agreement. However, notwithstanding the content of the final agreement, the UK no longer has a seat around the table and will find its influence in EU decision-making substantially reduced. As a result, the decision of the UK to leave the EU thus allows for a significant shift in the political leadership of the EU.

This shift can be expected to be considerable in the field of European finance, as the UK has had a strong impact on the development of policies and legislations dealing with European finance. From the perspective of coercive leadership, the UK has pre-Brexit benefitted from its status as one of the powerful member states, due to its size and power in decision-making as well as 
due to its authoritative role as being the home to the premier European financial centre. As most European financial transactions took place in the City of London, it became the nexus between European and international finance, and has allowed the UK to have a strong influence on the development of the European financial market. After Brexit, London would no longer be the financial capital of a major economic area. This calls into question the future of the City of London as a global financial centre. Historically speaking, the single time that a financial centre was able to grow into one of the global financial hubs, was the rebirth of, striking enough, London in the 1960 s as the financial capital of a medium economic power. Only after joining the EU London became the financial capital of a major economic area and satisfied the above requirement as a leading global centre (Cassis, 2018).

As the UK and the City of London do not want to lose their status as an international financial centre, and are reluctant to give up the ability to exercise leadership, a fight between the UK and other EU member states (as well as the European institutions) as emerged with regards to the potential move of the UK's financial sector to the EU27. Faced with a potential relocation of its industry, London is actively trying to sell its 'assets': The concentration of expertise in London, the UK's comparatively light-touch regulatory framework, the usage of English common law and the country's well-established financial infrastructure (Bank of England, 2015). After the publication of the white paper, in which the UK government stated not to seek single market access after Brexit (UK Government, 2017), the UK-based financial industry has recognized that it was unlikely to be able to preserve its EU passport and has started to advocate the usage of equivalence recognitions, assuring as much access as possible to the single market. The UK-based financial industry pointed out that equivalence agreements would provide significant benefits to EU customers, and that fragmentation would increase costs and risk.

As the UK has lost its voice in EU decision-making and faces the prospect of a potential move of (part of) its financial services industry, its ability to lead with regards to financial policies leadership is waning. This allows some of the EU27 member states to step in and fill the void, potentially providing these member states with more leadership in the governance of the European financial market. Internally, EU member states are divided on the question who would be best placed to provide this leadership and potentially serve as a new host to the UK's relocating financial industry. Clearly, in order to be able to exercise leadership, potential candidates to host a EU27 financial hub need to be powerful member states. The prospect of establishing a financial hub within the EU27, has spurred potential host countries to take a hard line with regards to the negotiations. For example, France and Germany (without opposition of other EU member states) have taken a strong stand on removing third country access for the UK financial indus- try, thereby supporting a relocation of the UK-based financial industry (Ringe, 2018).

Ever since Brexit, both these countries have also actively pursued an attraction strategy and have been promoting their national financial capitals as the next premier location for European finance in order to increase their potential leading role in the near future. Some other EU27 member states with second-tier financial centres and significant financial sectors also have the potential to gain from Brexit are Ireland (Dublin), Belgium (Brussels), the Netherlands (Amsterdam) and Luxembourg, but lack the cloud of Frankfurt and Paris, both politically and in terms of the strength of their respective financial industries.

Paris has struggled to survive as a major financial centre over the last century, due to its slow liberalization. However, the creation of Euronext, through the merger of the stock exchanges of Paris, Amsterdam, Brussels and Lisbon, ensures that Paris is now home to a major European stock exchange. In the aftermath of the Brexit vote, several initiatives have emerged to bring Paris back into the spotlight, whereby investors' associations, brokers, banks, and Euronext and Euroclear have joined French politicians in the battle (Quennouëlle-Corre, 2018). The relocation of the European Banking Authority to Paris, with competition from Brussels, Dublin, Frankfurt, Luxembourg, Prague, Vienna and Warsaw, has proven to be the first success story. At the same time, Germany has made relocating to Frankfurt more attractive. For example, the German Eurex has come up with a profit-sharing scheme on interest swaps and has announced to extend this to foreign exchange derivatives. German politicians have also regularly voiced their support for the creation of an EU27 financial hub in Frankfurt.

The push from both France and Germany for creating a financial hub in the Eurozone is not new and has been on the back of the minds of European leaders and institutions for a while. In January 2009, then French Minster Christine Lagarde (and now President of the European Central Bank) stated that euro-denominated transactions needed to be cleared in the euro area ("France wants ECB," 2009) instead of in the City of London, as the UK is not an eurozone member. In 2011, the European Central Bank followed suit and specified that large-scale clearing houses dealing with eurodenominated trades should be fully incorporated in the euro area, where the full operational and managerial control should be located (European Central Bank, 2011). The European Court of Justice eventually stated that the European Central Bank did not have the legal powers to require such a move as the European Central Bank lacks explicit regulatory competence with regards to the clearing of securities, which could only be obtained via an amendment of the Treaty on the Functioning of the European Union (General Court of the European Union, 2015). However, the issue has since been reopened. The European Securities and Markets Authority (2017) 
has issued a guidance stating that competition in regulatory and supervisory practices should be avoided, followed by the European Central Bank stating its concerns with out-of-eurozone supervision and its fear that Brexit might lead to the creation of shell companies within the Eurozone (European Central Bank, 2020). The position of the major European institutions clearly indicates that a decision to grant passporting rights to UK-based financial services would not be deemed favourable. If the UK loses its EU passport, third country financial services currently located in the UK, would need to relocate their operations and would have to set up European subsidiaries. As the City of London currently serves as a global financial centre, most of these third country operations are based in the UK. For example, the top five US investment banks locate about $90 \%$ of their European operations in London. In November 2016, the EU proposed new rules on intermediate parent undertaking, which would allow for more scrutiny by the European Central Bank, which could affect the UK as it might force UK and third country banks to have a capitalized subsidiarity in the EU. This was adopted in a slightly adapted version in 2019 (European Commission, 2019a). Adding to this, the European Central Bank in September 2020, increased the pressure on banks affected by Brexit as it is not convinced that enough people, assets, and resources had been transferred from London to the Eurozone to ensure a smooth functioning financial system post-Brexit (Arnold, 2020). As the supervisor of 25 new or restructured banking operations that because of Brexit have grown substantially, the European Central Bank wants to ensure that the Eurozone entities are structurally profitable and do not rely on excessive back to back bookings of the parent company. The European Central Bank has further emphasized that European financial products and consumers should be managed and controlled in the EU. As such, the equivalence discussions have bogged down in recriminations, and the fight over moving about $€ 1,2$ trillion of assets (four times the size of the total of EU27 financial assets in 2017), is yet again in a higher gear.

With both France and Germany looking to attract the UK-based financial industry, their potential to become leading hubs in European finance is rising. However, it is clear that this would also mean that the international influence of the City of London would diminish, rendering London a regional (like Singapore) rather than a global financial hub (such as New York). This would mean that the EU27's leadership in international finance would shrink. In the medium run, as a leading economic area, the EU would need to host one of the world's leading financial centres, one that can compete with the likes of New York, Shanghai, Hong Kong, Singapore or Tokyo, in the same way as London does today, unlike Paris or Frankfurt. Such a centre likely will have a stronger 'domestic' or European orientation, whereby London might still perform some of the international functions. The jury is out currently on whether
Paris and/or Frankfurt might become such a new international financial centre. Until that time, the fragmentation of the European financial services industry over several locations, will lead to higher costs and risks as no single location might achieve the necessary economics of scale. So, banks and consumers might end up with more expensive operations as fragmentation and overlapping EU27/London operations significantly increase costs. This will in hamper the prospect of EU influence in international finance (Wouters \& Van Kerckhoven, 2019).

Having established that France and/or Germany are most likely to lead future development in European financial governance, the question arises to what extent this would affect European financial policies. The UK has traditionally always had a large influence on financial governance as the promoter of a market-friendly environment for the financial industry and as the biggest non-eurozone country. Ideationally, the UK has always been a proponent of a more market-friendly approach towards the regulation of (financial) markets. Joined by several other EU member states, such as Ireland, the Netherlands, Luxembourg and the Scandinavian member states, the UK became a proponent of the marketmaking coalition, who generally favoured more marketfriendly regulations (Howarth \& Quaglia, 2017). Over the last decades, the UK has often fought strongly to ensure that EU financial regulation did not penalize their financial industry, and in doing so, represented the interests of several other EU27 member states. Examples include the UK (joined by the US) opposing to additional regulation of hedge funds (Fioretos, 2010), and defending fiercely market-friendly solutions to the Eurozone crisis, both at the EU level as well as globally (Wouters \& Van Kerckhoven, 2017). As a result, convergence between member states in financial regulation, and deeper financial integration has been more limited. Post-Brexit, this coalition will lose its strongest member. As a result, the 'New Hanseatic League' has emerged as a member state coalition composed of fiscally conservative and proliberalization member states, such as the Netherlands, Ireland, and the Nordic and Baltic states; with the aim to counterbalance the strengthened (and less economically liberal) Franco-German axis (Khan, 2018).

The market-friendly approach promoted by the UK often stood in stark contrast with the preference of other EU member states for a stronger rules-based approach. This market-shaping coalition includes member states such as Germany, France, Belgium, Italy, and the other Mediterranean countries. Germany in particular has been seeking to establish a rule-based culture in the EU financial market and discourages flexibility out of fear that allowing suppleness might undermine the entire system (Ringe, 2018).

After the financial crisis, the market-making coalition, led by the UK, was already losing momentum. After Brexit, it is to be expected that the market-shaping approach will come to dominate, as the leadership provided by Germany and France will grow. However, that 
does not necessarily mean that Germany and France will find themselves aligned in terms of ideational leadership, when it comes to the content of a stronger rule-based approach due to their historically different perspectives on European integration. Whereas Germany historically focused on economic harmonization and fiscal discipline, France can be seen as less strict and more in favour of governmental intervention. Both perspectives are also supported by a number of other EU27 member states. As an example, the German government has often been rather sceptical of redistributions, and bailout plans. It 'tacitly' approved the strong opposition of the 'New Hanseatic League' to larger bailout plans. In contrast, France is often more positively inclined towards redistributive measures. However, when Germany and France agree, they have been able to broker deals (or put the brakes on those deals they did not like) as a tandem (Degner \& Leuffen, 2020). Therefore, Brexit contributes to opening a reform window in eurozone governance. On the one hand, it creates an opportunity for a revival of Franco-German bilateralism, as both are committed to eurozone governance reforms, particularly in France after the election of Emmanuel Macron (Krotz \& Schild, 2018). On the other hand, the combined effects of Brexit and the French election have put pressure on Germany to accept more financial redistribution and risk-sharing (Coalition Treaty, 2018).

However, an ideational shift towards a more marketshaping approach could isolate the UK, which could provide additional challenges. A City of London that does not need to abide to more stringent EU rules could become an important competitor to the European financial centre(s) that might emerge. Freed from EU regulatory requirements, the UK financial regulator might, in the short run, pursue more deregulation attempting to attract EU business to the City, weakening the European (and global) financial system in return. The residual power of the City could then also place pressure on EU27 financial centres to compete on market-friendly terms. Even with a waning influence, the City will continue to exercise some influence, and will deploy its assets strategically in order to retain some power in EU and international finance. However, its direct leadership will be limited, and its ability to pursue this leadership through the international sphere might also be limited.

Additionally, as the most powerful non-eurozone country, the UK always defended the interests of the euro-outs as financial integration continued (Chang, 2017). With Brexit, the largest and strongest non-Eurozone economy in the EU is leaving. As a result, Brexit will shift the balance between the euro-ins and euro-outs. The latter now fear a second-class status, as they will have a much harder time resisting the attempts of the euro-ins of deepening the institutional, legal and political integration of financial markets. Brexit as such could thus lead to a clear multispeed Europe whereby the lines separating the Euro-ins and the Euro-outs deepen.

\section{Conclusions}

This article investigates the impact of Brexit on political leadership in the field of European finance. As a powerful member state and as the location of the premier financial hub in the EU, the UK has been able to significantly influence and provide leadership in European financial governance. Moreover, the UK, joined by some other EU member states, has been able to impose a market-making culture promoting lesser and more lax regulations than what some other member states, such as Germany and France would have preferred. As the largest non-eurozone EU member state, it has further been successful as a promoter of the interests of the euro-outs. As such, the UK was able to exercise significant ideational leadership.

Brexit changes all these dynamics. Post-Brexit, the UK will no longer have a direct influence on EU decisionmaking. Moreover, several EU member states and institutions have been advocating for the creation of a EU27 financial hub, which would relocate a significant part of the current UK-based financial services. Both these developments will lead to a substantial decline in the potential for UK political leadership.

France and Germany have already voiced their support for their respective national financial centres to replace London as the European financial hub. As both these countries are already among the most powerful member states in European finance, hosting the new EU27 financial hub would allow them to exercise even more political leadership. If France and/or Germany replace the UK as the leading European financial hub, it can be expected that this would also lead to a different type of ideational leadership. Both France and Germany would be in favour of more stringent regulation, particularly after the recent financial crises. A stronger rules-based approach towards the financial industry will replace the UK-backed more market-friendly approach. At the same time, this would leave some other marketfriendly member states isolated. They might be joined in their discontent with the changing leadership, due to Brexit, by non-eurozone countries, who might not be able to voice their concerns loudly anymore.

The residual power of the City could also place pressure on EU27 financial centres to compete on marketfriendly terms. Even with a waning influence, the City will continue to exercise some influence, and will deploy its assets strategically in order to retain some power in EU and international finance. However, its direct leadership will be limited, and its ability to pursue this leadership through the international sphere might also be limited.

\section{Acknowledgments}

This work was supported by the Erasmus + programme as a Jean Monnet Module on 'The Economics of European (Dis)Integration' (599986-EPP-1-2018-1-BEEPPJMO-MODULE). 


\section{Conflict of Interests}

The author declares no conflict of interests.

\section{References}

Armour, J. (2017). Brexit and financial services. Oxford Review of Economic Policy, 33(1), 54-69.

Arnold, M. (2020, September 9). European Central Bank supervisors turn the screw on banks' Brexit plans. Financial Times. Retrieved from https://www.ft. com/content/9b599f23-50bb-423f-87ed06a1f9d29542

Bank of England. (2015). Mapping the UK financial system. London: Bank of England Quarterly Bulletin.

Batsaikhan, U., Kalcik, R., \& Schoenmaker, D. (2017). Brexit and the European financial system: Mapping markets, players and jobs (Breugel Policy Contribution No. 2017/4). Brussels: Breugel.

Begg, I., \& Mushövel, F. (2016). The economic impact of Brexit: Jobs, growth and public finances. London: LSE. Retrieved from http://eprints.Ise.ac.uk/ 67008/1/Hearing-11---The-impact-of-Brexit-on-jobsand-economic-growth-sumary.pdf

Bloom, N., Bunn, P., Chen, S., Mizen, P., Smietanka, P., \& Thwaites, G. (2019). The impact of Brexit on UK firms (Working Paper No. 26218). Cambridge, MA: National Bureau of Economic Research.

Bulmer, S., \& Paterson, W. E. (2013). Germany as the EU's reluctant hegemon? Of economic strength and political constraints. Journal of European Public Policy, 20(10), 1387-1405.

Bunse, S. (2009). Small states and EU governance: Leadership through the Council Presidency. London: Palgrave Macmillan.

Burns, J. (1978). Leadership. New York, NY: Harper and Row.

Carstensen, M. B., \& Schmidt, V. A. (2018). Power and changing modes of governance in the euro crisis. Governance, 31(4), 609-624.

Cassis, Y. (2018). Introduction: A global overview from a historical perspective. In Y. Cassis \& D. Wojcik (Eds.), International financial centres after the global financial crisis and Brexit (pp. 1-16). Oxford: Oxford University Press.

Chang, M. (2017). Brexit and EMU: From EMU outsider to instigator (Working Paper No. 4/2017). Pisa: Scuola Superiore Sant'Anna.

Cini, M. (2008). Political leadership in the European Commission: The Santer and Prodi Commissions: 1995-2005. In J. Hayward (Ed.), Leaderless Europe (pp. 113-131). Oxford: Oxford University Press.

Coalition Treaty. (2018). Ein neuer Aufbruch für Europa, Eine neue Dynamik für Deutschland, Ein neuer Zusammenhalt für unser Land [A new departure for Europe, a new dynamic for Germany, a new cohesion for our country]. Berlin: Federal Government. Retrieved from https://www.bundesregierung.de/ resource/blob/656734/847984/5b8bc23590d4cb28 92b31c987ad672b7/2018-03-14-koalitionsvertragdata.pdf

Curtice, J. (2017). Why leave won the UK's EU referendum. Journal of Common Market Studies, 55(1), 19-37.

Daddow, O., \& Oliver, T. (2016). A not so awkward partner: The UK has been a champion of many causes in the EU. London: LSE. Retrieved from http:// eprints.Ise.ac.uk/66177/8/blogs.Ise.ac.uk_A_not_ so_awkward_partner_the_UK_has_been_a_ champion_of_many_causes_in_the_EU.pdf

De Ville, F., \& Siles-Brügge, G. (2019). The impact of Brexit on EU policies [Special issue]. Politics and Governance, 7(3), 1-92.

Degner, H., \& Leuffen, D. (2020). Brake and broker: Franco-German leadership for Saving EMU. Journal of European Public Policy. https://doi.org/10.1080/ 13501763.2020.1751678

Dinan, D. (2013). The post-Lisbon European Council Presidency: An interim assessment. West European politics, 36(6), 1256-1273.

Dupont, C., \& Moore, B. (2019). Brexit and the Eu in global climate governance. Politics and Governance, $7(3), 51-61$.

Elgie, R. (2001). Leadership: Political. In N. J. Smelser \& P. B. Baltes (Eds.), International encyclopedia of the social and behavioral sciences (pp. 8578-8580). Amsterdam: Elsevier.

European Central Bank. (2011). Eurosystem oversight policy framework. Frankfurt: European Central Bank.

European Central Bank. (2020). Relocating to the Euro area. European Central Bank. Retrieved from https://www.bankingsupervision.europa.eu/ banking/relocating/html/index.en.html

European Commission. (2019a). Directive (EU) 2019/878 of the European Parliament and of the Council of 20 May 2019 amending Directive 2013/36/EU as regards exempted entities, financial holding companies, mixed financial holding companies, remuneration, supervisory measures and powers and capital conservation measures. Brussels: European Commission.

European Commission. (2019b). Political declaration setting out the framework for the future relationship between the European Union and the United Kingdom. Brussels: European Commission.

European Securities and Markets Authority. (2017). Principles on the supervisory approach on relocations from the UK. Paris: European Securities and Markets Authority. Retrieved from https://www. esma.europa.eu/sites/default/files/library/esma7199-469_esma_issues_principles_on_supervisory_ approach_to_relocations_from_the_uk.pdf

Fioretos, O. (2010). Capitalist diversity and the international regulation of hedge funds. Review of International Political Economy, 17(3), 696-723.

France wants ECB to lead derivatives clearing push. 
(2009, January 19). Reuters. Retrieved from https://uk.reuters.com/article/eu-creditderivativesidUKLJ16478720090119

General Court of the European Union. (2015). Judgement in Case T-496/11 United Kingdom vs. European Central Bank. Luxembourg: General Court of the European Union. Retrieved from http://curia. europa.eu/jcms/upload/docs/application/pdf/201503/cp150029en.pdf

George, S. (1998). An awkward partner: Britain in the European Community (3rd ed.). Oxford: Oxford University Press.

Goodwin, M. J., \& Heath, O. (2016). The 2016 referendum, Brexit and the left behind: An aggregate-level analysis of the result. The Political Quarterly, 89(3), 323-332.

Howarth, D., \& Quaglia, L. (2017). Brexit and the single European financial market. Journal of Common Market Studies, 55(1), 149-164.

Howarth, D., \& Quaglia, L. (2018). Brexit and the battle for financial services. Journal of European Public Policy, 25(8), 1118-1136.

Jacobs, F. B. (2018). The EU after Brexit: Institutional and policy implications. London: Palgrave Macmillan.

Jensen, M., \& Snaith, H. (2018). Brexit and the European Union: Hanging in the balance? In P. Diamond, P. Nedergaard, \& B. Rosamond (Eds.), The Routledge handbook of the politics of Brexit (pp. 254-265). London: Routledge.

Keohane, R. O., \& Nye, J. (1989). Power and interdependence. Boston, MA: Little, Brown and Company.

Khan, M. (2018, July 19). EU's New Hanseatic League picks its next battle. Financial Times. Retrieved from https://www.ft.com/content/aedbe32a-8af7-11e8bf9e-8771d5404543

Koops, J. A., \& Tercovich, G. (2020). Shaping the European External Action Service and its post-Lisbon crisis management structures: An assessment of the EU High Representatives' political leadership. European Security, 29(3), 275-300.

Krotz, U., \& Schild, J. (2018). Back to the future? FrancoGerman bilateralism in Europe's post-Brexit Union. Journal of European Public Policy, 25(8), 1174-1193.

Lavery, S., McDaniel, S., \& Schmid, D. (2019). Finance fragmented? Frankfurt and Paris as European financial centres after Brexit. Journal of European Public Policy, 26(10), 1502-1520.

Milward, A. (1992). The European rescue of the nationstate. London: Routledge.

Moloney, N. (2016). International financial governance, the EU, and Brexit: The 'agencification' of EU financial governance and the implications. European Business Organization Law Review, 17, 451-480.

Moloney, N. (2018). Brexit and financial services: (Yet) another re-ordering of institutional governance for the EU financial system? Common Market Law Review, 55(3), 175-201.

Quennouëlle-Corre, L. (2018). Paris: The possibility of revival as an international financial centre. In Y. Cassis \& D. Wojcik (Eds.), International financial centres after the global financial crisis and Brexit (pp. 61-83). Oxford: Oxford University Press.

Rehman, S. R., \& Della Posta, P. (2018). The impact of Brexit on EU27 on trade, investments and financial services. Global Economy Journal, 18(1), 1-17.

Ringe, W.-G. (2018). The irrelevance of Brexit for the European financial market. European Business Organization Law Review, 19(1), 1-34.

Schild, J. (2010). Mission impossible? The potential for Franco-German leadership in the Enlarged EU. Journal of Common Market Studies, 48(5), 1367-1390.

Schoenmaker, D. (2017). The UK financial sector and EU integration after Brexit: The issue of passporting. In N. F. Campos \& F. Coricelli (Eds.), The economics of UK-EU relations: From the Treaty of Rome to the vote for Brexit (pp. 119-138). London: Palgrave Macmillan.

Shackleton, M. (2017). Transforming representative democracy in the EU? The role of the European Parliament. Journal of European Integration, 39(2), 191-205.

Tallberg, J. (2006). Leadership and negotiation in the European Union. Cambridge: Cambridge University Press.

Thompson, H. (2017). How the City of London lost at Brexit: A historical perspective. Economics and Society, 46(2), 211-228.

Tömmel, I. (2013). The presidents of the European Commission: Transactional or transforming leaders. Journal of Common Market Studies, 51(4), 789-805.

Tömmel, I. (2020). Political leadership in times of crisis: The Commission presidency of Jean-Claude Juncker. West European Politics, 43(5), 1141-1162.

Tömmel, I., \& Verdun, A. (2017). Political leadership in the European Union: An introduction. Journal of European Integration, 39(2), 103-112.

UK Government. (2017, February 2). The United Kingdom's exit from, and new partnership with, the European Union. UK Government. Retrieved from https://www.gov.uk/government/publications/theunited-kingdoms-exit-from-and-new-partnershipwith-the-european-union-white-paper

UK Government's Actuary Department. (2017). Investment news: Monthly bulletin form the insurance and investment team. London: UK Government's Actuary Department. Retrieved from https:// assets.publishing.service.gov.uk/government/ uploads/system/uploads/attachment_data/file/ 629670/Jun_2017_update.pdf

Van Kerckhoven, S., \& Odermatt, J. (2020). Euro clearing after Brexit: Shifting locations and oversight. Journal of Financial Regulation and Compliance. https:// doi.org/10.1108/JFRC-02-2020-0021

Verdun, A. (2017). Political leadership of the European Central Bank. Journal of European Integration, 39(2), 207-221. 
Wood, P. R. (2008). Maps of world financial law. London: Sweet and Maxwell.

Wouters, J., \& Van Kerckhoven, S. (2017). Preserving consensus. In J. Kirton (Ed.), G7 Italy, the Taormina Summit (pp. 120-121). Toronto: Munk School of Global Affairs and Public Policy.

Wouters, J., \& Van Kerckhoven, S. (2019). The role of the EU in the $\mathrm{G} 7$ in the era of Brexit and Trump. In
C. Oldani \& J. Wouters (Eds.), The G7, anti-globalism and the governance of globalization (pp. 68-89). London: Routledge.

Wouters, J., Van Kerckhoven, S., \& Odermatt, J. (2013). The EU at the G20 and the G20's impact on the EU. In B. Van Vooren, S. Blockmans, \& J. Wouters (Eds.), The EU's role in global governance: The legal dimension (pp. pp. 259-272). Oxford: Oxford University Press.

\section{About the Author}

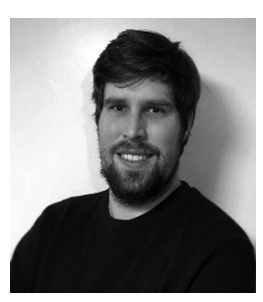

Sven Van Kerckhoven is a Professor of Business and Economics at Vesalius College, and a Research Professor in European Economic Governance at the Institute for European Studies (Vrije Universiteit Brussel). He also serves as Vice-Dean for Education at both institutions and coordinates a Jean Monnet Module on the economics of European (dis)integration. His research focuses on global economic governance. 